\title{
Molecular Hydrogen Yields from the Alpha Self-Radiolysis of Nitric Acid Solutions Containing Plutonium or Americium
}

Gregory P. Horne, Robin M. Orr, Simon M. Pimblott, Howard E. Sims, Robin J. Taylor, Kevin J. Webb, Colin R. Gregson

February 2018

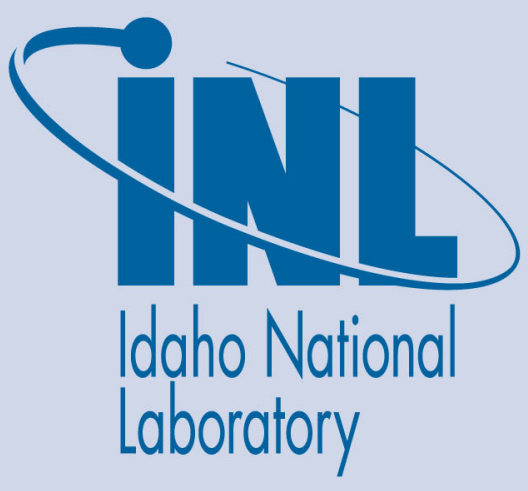

The INL is a U.S. Department of Energy National Laboratory operated by Battelle Energy Alliance 


\title{
Molecular Hydrogen Yields from the Alpha Self- Radiolysis of Nitric Acid Solutions Containing Plutonium or Americium
}

\author{
Gregory P. Horne, Robin M. Orr, Simon M. Pimblott, Howard E. Sims, Robin J. \\ Taylor, Kevin J. Webb, Colin R. Gregson
}

February 2018

Idaho National Laboratory Idaho Falls, Idaho 83415

http://www.inl.gov

Prepared for the U.S. Department of Energy Office of Nuclear Energy Under DOE Idaho Operations Office Contract DE-AC07-05ID14517, DE-AC07-05ID14517 


\title{
Molecular Hydrogen Yields from the Alpha Self-Radiolysis of Nitric Acid Solutions Containing Plutonium or Americium
}

\author{
Colin R. Gregson, ${ }^{a}$ Gregory P. Horne, ${ }^{\mathrm{b}, \mathrm{c}, \mathrm{d},{ }^{*}}$ Robin M. Orr, ${ }^{\mathrm{a}, *}$ Simon M. Pimblott, ${ }^{\mathrm{b}, \mathrm{d}}$ Howard E. \\ Sims, ${ }^{\mathrm{e}}$ Robin J. Taylor, ${ }^{\mathrm{a}}$ Kevin J. Webb ${ }^{\mathrm{a}}$ \\ ${ }^{a}$ National Nuclear Laboratory, Central Laboratory, Sellafield, Seascale CA20 1PG, UK \\ ${ }^{b}$ Dalton Cumbria Facility, University of Manchester, Westlakes, Moor Row, Whitehaven CA24 \\ $3 H A$, UK \\ ${ }^{c}$ University of Manchester, School of Chemistry, Oxford Road, Manchester M13 9PL, UK \\ ${ }^{d}$ Idaho National Laboratory, University Boulevard, Idaho Falls, Idaho, 83402, USA \\ ${ }^{e}$ National Nuclear Laboratory, Culham Science Centre, Abingdon, Oxfordshire, OX14 3DB, UK \\ *Corresponding authors: gregory.horne@inl.gov and robin.m.orr@nnl.co.uk
}

\begin{abstract}
The yield of molecular hydrogen, as a function of nitric acid concentration, from the $\alpha$ radiolysis of aerated nitric acid and its mixtures with sulfuric acid containing plutonium or americium has been investigated. Comparison of experimental measurements with predictions of a Monte Carlo radiation track chemistry model shows that, in addition to scavenging of the hydrated electron, its precursor, and the hydrogen atom, the quenching of excited state water is important in controlling the yield of molecular hydrogen. In addition, increases in solution acidity cause a significant change in the track reactions that can be explained as resulting from scavenging of $\mathrm{e}_{\mathrm{aq}}{ }^{-}$by $\mathrm{H}_{\mathrm{aq}}{ }^{+}$to form $\mathrm{H}^{*}$. While plutonium has been shown to be an effective scavenger of precursors of molecular hydrogen below $0.1 \mathrm{~mol} \mathrm{dm}^{-3}$ nitrate, previously reported effects of plutonium on $\mathrm{G}\left(\mathrm{H}_{2}\right)_{\alpha}$ between 1 and $10 \mathrm{~mol} \mathrm{dm}^{-3}$ nitric acid were not reproduced. Modelling results suggest that plutonium is unlikely to effectively compete with nitrate ions in scavenging the precursors of molecular hydrogen at higher nitric acid concentrations and this was confirmed by comparing molecular hydrogen yields from plutonium solutions with those from americium solutions. Finally, comparison between radionuclide, ion accelerator experiments and model predictions leads to the conclusion that the high dose rate of accelerator studies does not significantly affect the measured molecular hydrogen yield. These reactions provide insight into the important processes for liquors common in the reprocessing of spent nuclear fuel and the storage of highly radioactive liquid waste prior to vitrification.
\end{abstract}

\section{INTRODUCTION}

Molecular hydrogen $\left(\mathrm{H}_{2}\right)$ production from the radiolysis of aqueous solutions, liquids, and solids is a potential hazard in the nuclear industry because of the possible formation of flammable gas mixtures and pressurisation of sealed containers, such as plutonium $(\mathrm{Pu})$ oxide 
canisters. Aqueous nitric acid $\left(\mathrm{HNO}_{3}\right)$ solutions are used throughout the nuclear industry for the dissolution of spent nuclear fuel (SNF) and nuclear materials, in SNF reprocessing facilities, and in analytical laboratories. Nitrate anions $\left(\mathrm{NO}_{3}{ }^{-}\right)$, present in solutions of nitric acid $\left(\mathrm{HNO}_{3} \rightleftharpoons \mathrm{NO}_{3}{ }^{-}+\mathrm{H}_{\mathrm{aq}}{ }^{+}, \mathrm{pK}_{\mathrm{a}} \approx 1.37\right)^{1}$, are particularly important in the radiolysis of water because they are known to efficiently scavenge the precursors to radiolytic $\mathrm{H}_{2}$ formation (i.e. the pre-solvated electron $\left(\mathrm{e}_{\mathrm{pre}}{ }^{-}\right)$, the hydrated electron $\left(\mathrm{e}_{\mathrm{aq}}{ }^{-}\right)$, the hydrogen atom $\left(\mathrm{H}^{\bullet}\right)$, and excited state water $\left.\left(\mathrm{H}_{2} \mathrm{O}^{*}\right)^{2}\right)$, to the extent that at high concentrations of nitrate and nitric acid the $\mathrm{H}_{2}$ yield from water radiolysis is significantly reduced compared with that from pure water. ${ }^{3}$

There is a large amount of data in the literature for $\mathrm{H}_{2}$ yields, $\mathrm{G}\left(\mathrm{H}_{2}\right)$, from the gamma $(\gamma)$ radiolysis of aqueous nitrate and nitric acid solutions, ${ }^{4-14}$ summarised in Figure 1, due to longstanding interests in the effects of $\mathrm{e}_{\mathrm{aq}}{ }^{-}$scavengers on the $\mathrm{G}\left(\mathrm{H}_{2}\right)$ and in elucidating the fundamental mechanistic radiation chemistry of water. With the exception of a small number of results, data from these studies of $\gamma$-radiolysis are very consistent, implying that molecular hydrogen yields for nitrate and nitric acid solutions are not significantly different. At low nitrate concentrations $\mathrm{G}\left(\mathrm{H}_{2}\right)_{\gamma}$ tends towards that for pure water $\mathrm{G}\left(\mathrm{H}_{2}\right)_{\gamma}=0.44$ molecules $(100 \mathrm{eV})^{-1}$ $\left(25{ }^{\circ} \mathrm{C}\right),{ }^{15}$ but above $\sim 0.01 \mathrm{~mol} \mathrm{dm}^{-3}$ nitrate concentration $\mathrm{G}\left(\mathrm{H}_{2}\right)_{\gamma}$ decreases until it is largely suppressed at sufficiently high concentrations, e.g. $\mathrm{G}\left(\mathrm{H}_{2}\right)_{\gamma}=0.02$ molecules $(100 \mathrm{eV})^{-1}$ for $6 \mathrm{~mol} \mathrm{dm}^{-3}$ nitrate. Throughout this work, radiolytic yields will be expressed as G-values quoted in the conventional radiation chemical unit of ions or molecules $(100 \mathrm{eV})^{-1}$, the corresponding S.I. unit is related by 1 ion or molecule $(100 \mathrm{eV})^{-1}=0.104 \mu \mathrm{mol} \mathrm{J} \mathrm{J}^{-1}$. In contrast, there are relatively few measurements of $\mathrm{H}_{2}$ yields due to alpha ( $\left.\alpha-\right)$ radiolysis of nitrate and nitric acid solutions. This is due to the need for specialised facilities for safe handling of $\alpha$-emitting radionuclides. Previous $\alpha$-studies, also shown in Figure 1 , used Pu (Table 1), ${ }^{10,16,17,18}{ }^{210} \mathrm{Po}\left(\tau_{1 / 2}=\right.$ 138.376 days, $5.3 \mathrm{MeV} \alpha$-particle $),{ }^{19}$ or ${ }^{244} \mathrm{Cm}\left(\tau_{1 / 2}=18.10 \text { years, } 5.8 \mathrm{MeV} \alpha \text {-particle }\right)^{20}$ as $\alpha$ radiation sources in nitrate or nitric acid solutions, in some cases with the addition of sulfuric acid $\left(\mathrm{H}_{2} \mathrm{SO}_{4}\right)$. The $\mathrm{H}_{2}$ yields for $\alpha$-radiolysis are larger than for $\gamma$-radiolysis as a consequence of the higher linear energy transfer (LET) of $\alpha$-particles; higher LETs result in shorter radiation tracks with more closely spaced spurs in which second order processes favour molecular yields over radical yields. ${ }^{21}$ As is the case for $\gamma$-irradiation, increasing the nitrate concentration above $0.01 \mathrm{~mol} \mathrm{dm}^{-3}$ decreases $\mathrm{G}\left(\mathrm{H}_{2}\right)_{\alpha}$, resulting in almost complete suppression at sufficiently high nitrate concentrations. Alpha-irradiation data are particularly sparse at nitrate concentrations 
below $1.0 \mathrm{~mol} \mathrm{dm}{ }^{-3}$ nitrate, which is the range most sensitive to nitrate concentration. Furthermore, the limiting $\mathrm{H}_{2}$ yield at low nitrate concentrations should tend towards values of pure water or those for aqueous sulfuric acid solutions, but values reported in the literature show considerable scatter. ${ }^{20,22,23,24}$ 


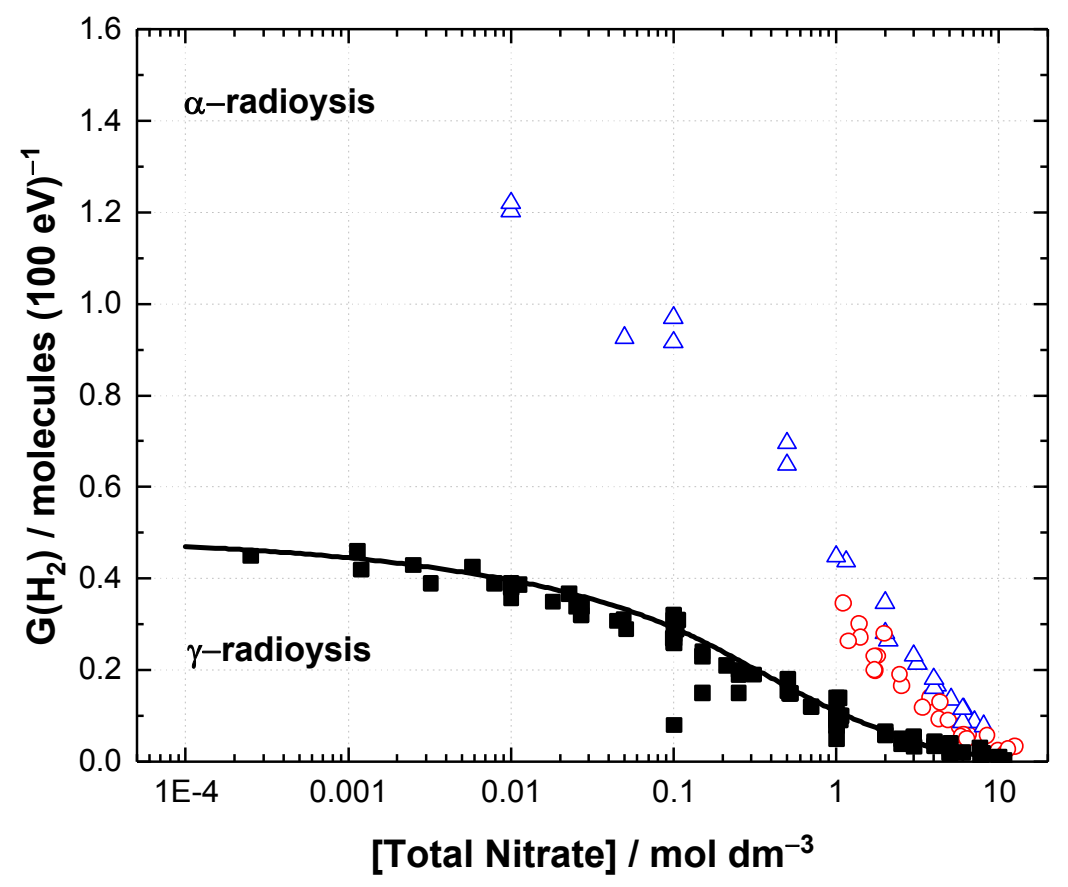

Figure 1. Comparison of available literature data for $\mathrm{G}\left(\mathrm{H}_{2}\right)$ from gamma $(\boldsymbol{\square})^{4-14}$ and alpha (plutonium $\bigcirc^{10, E r r o r ! ~ B o o k m a r k ~ n o t ~ d e f i n e d .-E r r o r ! ~ B o o k m a r k ~ n o t ~ d e f i n e d . ~}$ Bookmark not defined.,Error! Bookmark not defined.) radiolysis of aerated aqueous nitrate and nitric acid solutions. The solid curve is from stochastic radiation track calculations. ${ }^{2}$

Table 1. Isotopic composition of plutonium solutions used in previous studies.

\begin{tabular}{l|l|l|l|l|l}
\hline Reference & $\begin{array}{l}{ }^{238} \mathbf{P u} \\
(\%)\end{array}$ & $\begin{array}{l}{ }^{239} \mathbf{P u} \\
(\%)\end{array}$ & $\begin{array}{l}{ }^{240} \mathbf{P u} \\
(\%)\end{array}$ & $\begin{array}{l}{ }^{241} \mathbf{P u} \\
(\%)\end{array}$ & $\begin{array}{l}{ }^{242} \mathbf{P u} \\
(\%)\end{array}$ \\
\hline$\tau_{1 / 2}$ (years) & 87.7 & 24114 & 6563 & 14.4 & 373500 \\
\hline$\alpha$-particle $(\mathrm{MeV})$ & 5.49 & 5.15 & 5.16 & & 4.89 \\
\hline Kazanjian et al. $[10]$ & 80 & & & & \\
\hline Kazanjian et al. $[16]$ & 0.01 & 93.72 & 5.86 & 0.39 & 0.022 \\
\hline Sheppard [17] & 0.03 & Balance & $7.5-8.4$ & & \\
\hline \multirow{2}{*}{ Kuno et al. $[18]$} & 1.17 & 62.83 & 23.51 & 8.46 & 4.01 \\
\cline { 2 - 6 } & 0.0037 & 74.37 & 19.50 & 4.22 & 1.88 \\
\hline
\end{tabular}

Early measurements by Lefort ${ }^{25,26}$ using ${ }^{222} \mathrm{Rn}\left(\tau_{1 / 2}=3.82\right.$ days, $5.5 \mathrm{MeV} \alpha$-particle $)$ or ${ }^{210}$ Po as an $\alpha$-source gave $\mathrm{G}\left(\mathrm{H}_{2}\right)_{\alpha}$ between 1.7 and 1.8 under both aerated and deaerated conditions for pure water, as well as acidic and alkaline solutions, whereas Senvar and $\operatorname{Hart}^{27}$ measured $\mathrm{G}\left(\mathrm{H}_{2}\right)_{\alpha}$ $=1.45$ using ${ }^{210} \mathrm{Po}$ as an external source. These $\mathrm{G}\left(\mathrm{H}_{2}\right)_{\alpha}$ values compare with measurements 
obtained using cyclotron $5 \mathrm{MeV}$ helium ion $\left({ }^{4} \mathrm{He}^{2+}\right)$ irradiation, $\mathrm{G}\left(\mathrm{H}_{2}\right)_{\alpha}=1.2-1.3$ for deaerated pure water. $^{28,29}$ There is some concern over utilising particle accelerators as a substitute for radionuclide studies: ${ }^{4} \mathrm{He}^{2+}$ beams from accelerators normally deliver very high local dose-rates due to the ion currents used and the very small penetration of the ions into the target solution. For instance, $5.5 \mathrm{MeV}^{4} \mathrm{He}^{2+}$ ions, which are of comparable energy to $\alpha$-emission from plutonium and americium, have a range in water of $\sim 44 \mathrm{~m}^{30}$, so at $1 \mathrm{nA}$ current and $0.5 \mathrm{~cm}$ beam diameter an ion beam delivers a dose rate of $10 \mathrm{MGy} \mathrm{hr}^{-1}$ in the irradiated volume; this compares with $6 \times 10^{-6}$ to $6 \times 10^{-4} \mathrm{MGy} \mathrm{hr}^{-1}$ for the plutonium solutions used in this study. Consequently, the validity of comparing radionuclide and accelerator ${ }^{4} \mathrm{He}^{2+}$ ion beams studies based on average solution dose rates may be questioned. ${ }^{31}$

The present work investigates the $\mathrm{H}_{2}$ yields from the $\alpha$-radiolysis of aerated aqueous nitric acid solutions through a combination of experimental studies using the self-radiolysis of plutonium and americium nitric acid solutions combined with stochastic radiation track modelling calculations. The main focus of these experiments was to: (i) provide greater insight into the $\alpha$-radiolytic production of $\mathrm{H}_{2}$ from nitric acid solutions with concentrations below $1 \mathrm{~mol} \mathrm{dm}{ }^{-3}$, as this is where the $\mathrm{H}_{2}$ yields have the greatest uncertainty; and (ii) determine whether or not $\mathrm{G}\left(\mathrm{H}_{2}\right)_{\alpha}$ is subject to significant dose rate effects, i.e. whether particle accelerator studies are a representative and viable alternative to studies using radionuclides.

\section{MATERIALS AND METHODS}

\section{Experimental}

Chemicals. Nitric acid (99.995\% trace metals basis), sulfuric acid (Certified ACS grade), and sodium hydroxide (Certified ACS grade) were supplied by Fisher Scientific. Plutonium and americium nitrate were supplied by the National Nuclear Laboratory. The plutonium isotopic distribution of the plutonium nitrate and plutonium sulphate solutions were measured by mass spectrometry and corrected for subsequent radioactive decay of plutonium and ingrowth of

${ }^{241} \mathrm{Am}\left({ }^{241} \mathrm{Pu} \rightarrow{ }^{241} \mathrm{Am}+\beta^{-}+\bar{v}, \tau_{1 / 2}=14.4\right.$ years $)$. The calculated isotopic distributions of the stock solutions at the time of these experiments are given in SI Table 1. All chemicals were used as received without further purification. Ultra-pure water was used to make up all aqueous solutions. 
Actinide Solution Preparation. The composition of plutonium (Pu1-Pu33) and americium nitrate solutions (Am1-Am7) are detailed in Tables 2 and 3 of the Supporting Information (SI). Three series of plutonium experiments were performed: Pu1-Pu11 varied nitrate concentration between $0.1-1.3 \mathrm{~mol} \mathrm{dm}^{-3}$ at approximately constant plutonium concentration $(\sim 50 \mathrm{mM})$; Pu12-Pu29 varied plutonium concentration at 1.6, 1.6, and $160 \mathrm{mM}$ and varied nitrate concentrations at approximately 2.5, 0.25 and $5 \times 10^{-2} \mathrm{~mol} \mathrm{dm}^{-3}$; Pu30-Pu33 maintained constant plutonium concentration $(\sim 0.24 \mathrm{mM})$ and varied nitric acid concentration between $0.1-6.0 \mathrm{~mol} \mathrm{dm}{ }^{-3}$. Reducing the acidity below $1 \mathrm{~mol} \mathrm{dm}^{-3} \mathrm{H}_{\mathrm{aq}}{ }^{+}$tends to hydrolyse and precipitate plutonium, particularly below $0.1 \mathrm{~mol} \mathrm{dm}^{-3} \mathrm{H}_{\mathrm{aq}}{ }^{+32}$ For this reason, measurements for solutions with nitrate concentrations $<0.8 \mathrm{~mol} \mathrm{dm}^{-3}$ used solutions of plutonium sulphate in sulfuric acid with the appropriate nitrate concentration added.

Plutonium nitrate solutions were prepared by small additions of concentrated nitric acid to diluted stock solutions of plutonium(IV) nitrate. Plutonium sulphate solutions were made by neutralising plutonium(IV) nitrate with sodium hydroxide solution to precipitate plutonium(IV) hydroxide. The precipitate was washed and dissolved in $2.2 \mathrm{~mol} \mathrm{dm}^{-3}$ sulfuric acid (Pu1-Pu9) or $0.75 \mathrm{~mol} \mathrm{dm}^{-3}$ sulfuric acid (Pu18-Pu29). The precipitation, washing, and dissolution steps were repeated. For experiments with mixed nitrate and sulphate solutions, small volumes of concentrated nitric and sulfuric acid were added to the plutonium sulphate solutions and diluted to the appropriate volume. Americium solutions were prepared by dilution of an americium nitrate stock solution of purity $>99 \%{ }^{241} \mathrm{Am}\left(\tau_{1 / 2}=432.2\right.$ years, $\left.5.637 \mathrm{MeV}\right)$ with small volumes of concentrated nitric and sulfuric acid. Low nitrate concentration solutions (Am1-Am3) had $0.75 \mathrm{~mol} \mathrm{dm}^{-3}$ sulfuric acid added for consistency with the corresponding plutonium experiments. In all cases the solutions were aerated and solution volumes were $0.5 \mathrm{~mL}$ except experiments Pu30-Pu33 and Am4-Am7 where 5 mL was used.

Hydrogen Yield Measurements. Molecular hydrogen production was generally determined by repeatedly sampling the headspace gas of each vessel over time, replacing the sampled gas with laboratory air. However, in a small number of experiments (Pu30-33 and Am4-Am7, indicated by asterisk in SI Tables 1 and 2) $\mathrm{H}_{2}$ production was determined by preparing several identical vessels that were each sampled only once at different times. Molecular hydrogen concentrations were measured by gas chromatography using an Agilent Micro Gas Chromatograph-3000 ( $\mu \mathrm{GC}$ ) operating with a single channel molsieve $5 \AA$ column, 
thermal conductivity detector and argon carrier gas. $\mathrm{G}\left(\mathrm{H}_{2}\right)$ values were determined from the slope of the $\mathrm{H}_{2}$ produced $v s$. time plots, for example see SI Figure 1, and the total $\alpha$-dose rate to the solution. Molecular hydrogen was generated at a constant rate over the duration of measurements. The $\alpha$-dose rates were calculated from the respective activities of the actinide solutions and were corrected for decay of the various isotopes and the ingrowth of additional radionuclides. Uncertainties in $\mathrm{G}\left(\mathrm{H}_{2}\right)_{\alpha}$ were estimated from the standard error in the slope of $\mathrm{H}_{2}$ production vs. time, with uncertainty in the plutonium and americium concentration and the isotopic composition being taken to be small, and error bars are plotted as the $95 \%$ confidence interval.

\section{Stochastic Radiation Track Simulations}

Radiation track simulations used a stochastic modelling code which has been described in detail previously. ${ }^{33}$ Both $\gamma$ - and $\alpha$-radiolysis track simulations were performed for aerated $\left(\left[\mathrm{O}_{2}\right]=2.5 \times 10^{-4} \mathrm{~mol} \mathrm{dm}^{-3}\right)$ aqueous nitric acid solutions. For the $\alpha$-simulations an array of energies were simulated $(0.1-6 \mathrm{MeV})$, and the resulting $\mathrm{H}_{2}$ yields were then integrated to $5 \mathrm{MeV}$ to derive the presented $\mathrm{G}\left(\mathrm{H}_{2}\right)_{\alpha}$ values. The simulations followed the evolution of the radiation track up to $1 \mu$ s to allow for complete spatial relaxation. Direct radiation effects on nitrate and nitric acid were not included in track calculations as their products $\left(\mathrm{NO}_{3}{ }^{\circ}, \mathrm{e}^{-}, \mathrm{HNO}_{2}, \mathrm{NO}_{2}{ }^{-}\right.$, and $\left.\mathrm{O}\left({ }^{3} \mathrm{P} /{ }^{1} \mathrm{D}\right)\right)$ do not impinge upon the radiolytic yield of $\mathrm{H}_{2}$. This is because at the total nitrate concentrations that coincide with direct radiolysis $\left(\geq 1 \mathrm{~mol} \mathrm{dm}^{-3}\right)$ the majority of $\mathrm{H}_{2}$ is formed through the decomposition of excited state water $\left(\mathrm{H}_{2} \mathrm{O}^{*}\right)$ and not through inter/intra-track chemistry.

\section{RESULTS}




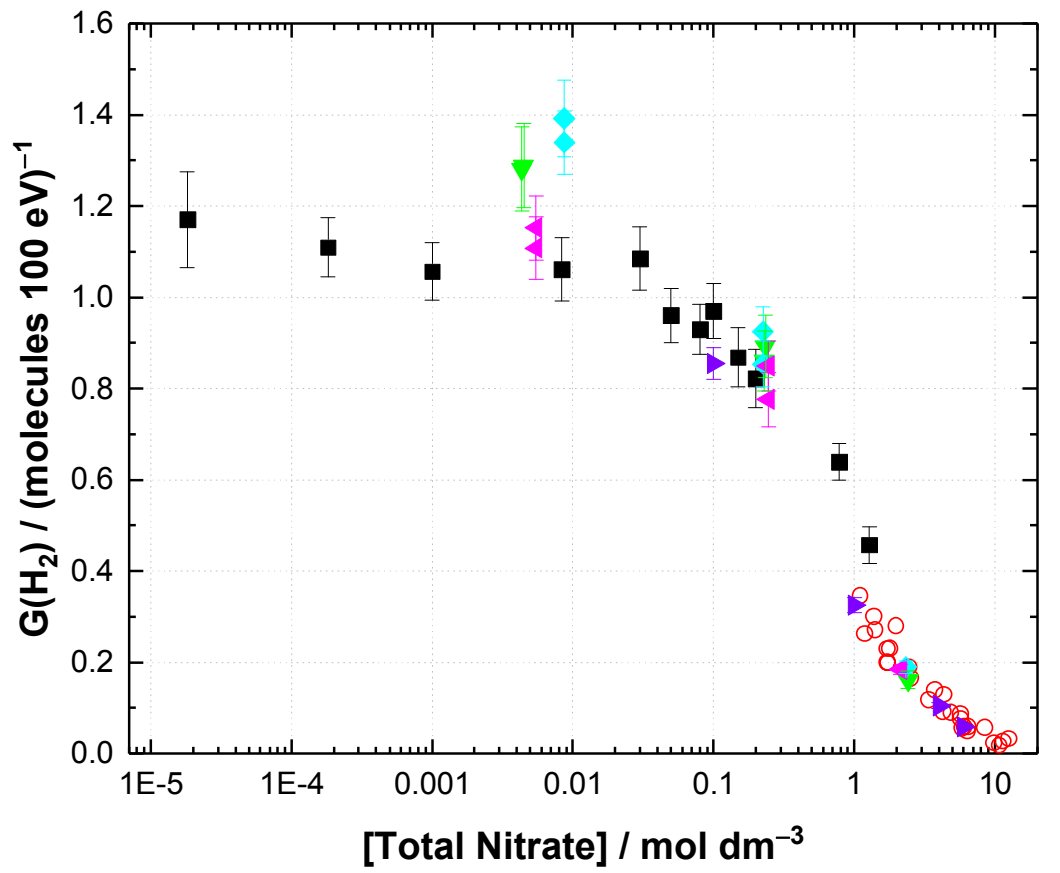

Figure 2. $\mathrm{G}\left(\mathrm{H}_{2}\right)_{\alpha}$ from self-radiolysis by plutonium in nitic acid solutions as a function of total nitrate concentration for plutonium concentrations: $50 \mathrm{mM}(\boldsymbol{\nabla}), 1.6 \mathrm{mM}(\nabla), 16 \mathrm{mM}(\diamond)$, $160 \mathrm{mM}(\triangleleft), 0.24 \mathrm{mM}(\diamond)$, and the available plutonium literature $(O)^{10, \text { Error! Bookmark not defined.- }}$ Error! Bookmark not defined.

Figure 2 and 3 summarise the $\mathrm{G}\left(\mathrm{H}_{2}\right)_{\alpha}$ yields from self-radiolysis by plutonium and americium in nitric acid solutions as a function of total nitrate in solution. As with the previously shown $\gamma$-radiolysis data, $\mathrm{G}\left(\mathrm{H}_{2}\right)_{\alpha}$ decreases with increasing nitric acid concentration for both plutonium and americium solutions. These $\mathrm{G}\left(\mathrm{H}_{2}\right)_{\alpha}$ values are in good agreement with the literature data for plutonium solutions in the $1-10 \mathrm{~mol} \mathrm{dm}^{-3}$ nitrate concentration range. ${ }^{\text {Error! }}$ Bookmark not defined.-Error! Bookmark not defined. At lower nitrate concentrations $\left(<0.01 \mathrm{~mol} \mathrm{dm}^{-3}\right)$, greater variation in the results was observed with $\mathrm{G}\left(\mathrm{H}_{2}\right)_{\alpha}$ values for lower plutonium concentrations of 1.6 and $16 \mathrm{mM}$ being higher than for higher plutonium concentrations of 50 and $160 \mathrm{mM}$, indicating that plutonium ions may have a modest influence on the radiolytic generation of $\mathrm{H}_{2}$ in this $\mathrm{HNO}_{3}$ concentration regime. 


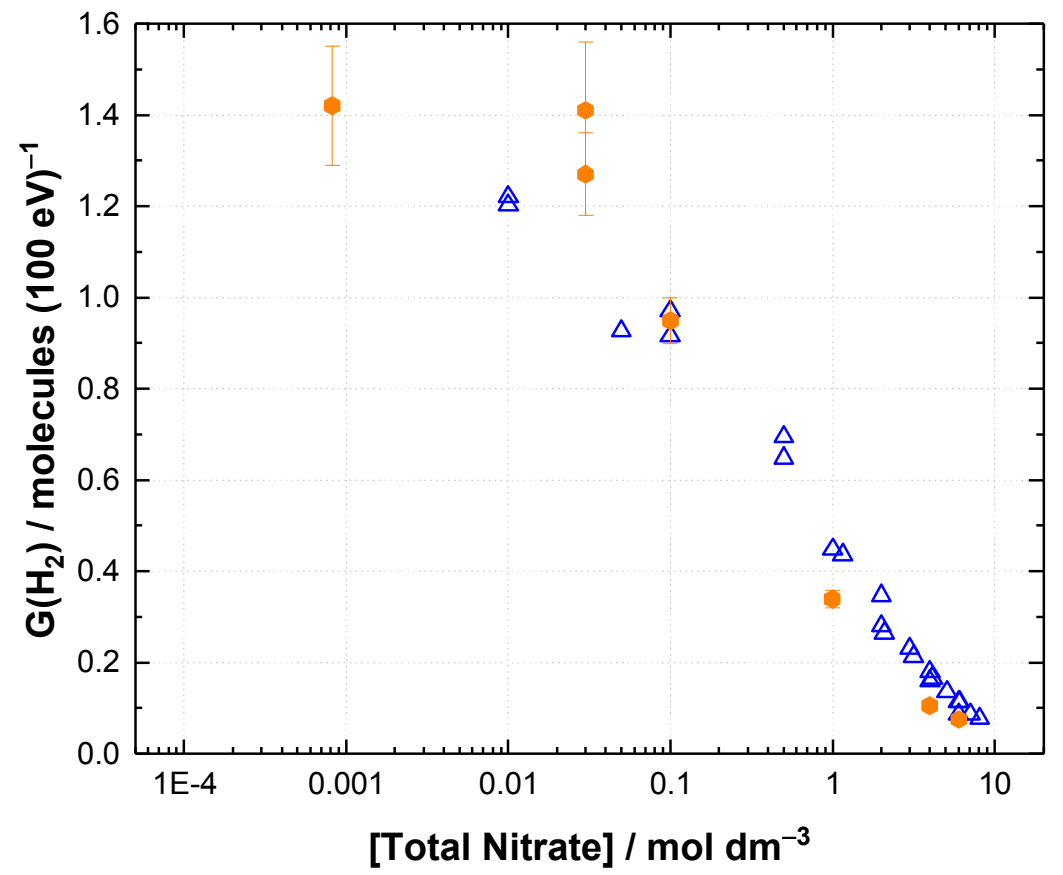

Figure 3. $\mathrm{G}\left(\mathrm{H}_{2}\right)_{\alpha}$ from self-radiolysis by americium in nitic acid solutions as a function of total nitrate concentration: $1.6 \mathrm{mM}{ }^{241} \mathrm{Am}(\triangle)$ and the available polonium and curium $(\triangle)^{\text {Error! }}$ Bookmark not defined.,Error! Bookmark not defined.

The $\mathrm{G}\left(\mathrm{H}_{2}\right)_{\alpha}$ values for americium solutions are in very good agreement with those from the corresponding plutonium data between 1 and $10 \mathrm{~mol} \mathrm{dm}^{-3}$, falling systematically below data reported for curium and polonium solutions. For lower nitrate concentrations, the americium $\mathrm{G}\left(\mathrm{H}_{2}\right)_{\alpha}$ values are closer in agreement to the higher values measured for low plutonium concentration solutions shown in Figure 2. Comparison of the $\mathrm{G}\left(\mathrm{H}_{2}\right)_{\alpha}$ values for these two radionuclides at low nitrate concentrations indicates a limiting $\mathrm{H}_{2}$ yield between 1.2 and 1.4, in agreement with measurements obtained using cyclotron $5 \mathrm{MeV}^{4} \mathrm{He}^{2+}$ irradiation. $^{28,29}$

\section{DISCUSSION}

Effect of Nitrate Concentration on Molecular Hydrogen Yield. The initial chemistry in the radiolysis of water is generally agreed to proceed via reactions $\mathbf{1}-\mathbf{1 5}$. $2,15,21,34,35,36$

$$
\begin{aligned}
& \mathrm{H}_{2} \mathrm{O} m \mathrm{H}_{2} \mathrm{O}^{+}+\mathrm{e}^{-} \\
& \mathrm{H}_{2} \mathrm{O} \rightsquigarrow \mathrm{H}_{2} \mathrm{O}^{*}
\end{aligned}
$$




$$
\begin{array}{ll}
\mathrm{H}_{2} \mathrm{O}^{*} \rightarrow \mathrm{H}^{\bullet}+\mathrm{OH}^{\bullet} & \\
\mathrm{H}_{2} \mathrm{O}^{*} \rightarrow \mathrm{H}_{2}+\mathrm{O}^{\bullet} & k \sim 4.3 \times 10^{12} \mathrm{dm}^{3} \mathrm{~mol}^{-1} \mathrm{~s}^{-1} \\
\mathrm{H}_{2} \mathrm{O}^{\bullet+}+\mathrm{e}^{-} \rightarrow \mathrm{H}_{2} \mathrm{O}^{*} & k=1.8 \times 10^{11} \mathrm{dm}^{3} \mathrm{~mol}^{-1} \mathrm{~s}^{-1} \\
\mathrm{H}_{2} \mathrm{O}^{\bullet+}+\mathrm{H}_{2} \mathrm{O} \rightarrow \mathrm{OH}^{\bullet}+\mathrm{H}_{3} \mathrm{O}^{+} & k=2.3 \times 10^{10} \mathrm{dm}^{3} \mathrm{~mol}^{-1} \mathrm{~s}^{-1} \\
\mathrm{e}^{-} \stackrel{110 f s}{\longrightarrow} \mathrm{e}_{\mathrm{pre}}{ }^{-240 f s} \longrightarrow \mathrm{e}_{\mathrm{aq}}{ }^{-} & k=5.5 \times 10^{9} \mathrm{dm}^{3} \mathrm{~mol}^{-1} \mathrm{~s}^{-1} \\
\mathrm{e}_{\mathrm{aq}}{ }^{-}+\mathrm{H}_{\mathrm{aq}}{ }^{+} \rightarrow \mathrm{H}^{\bullet} & k=2.5 \times 10^{10} \mathrm{dm}^{3} \mathrm{~mol}^{-1} \mathrm{~s}^{-1} \\
2 \mathrm{e}_{\mathrm{aq}}{ }^{-}+2 \mathrm{H}_{2} \mathrm{O} \rightarrow \mathrm{H}_{2}+2 \mathrm{OH}^{-} & k=3.0 \times 10^{10} \mathrm{dm}^{3} \mathrm{~mol}^{-1} \mathrm{~s}^{-1} \\
\mathrm{e}_{\mathrm{aq}}{ }^{-}+\mathrm{H}^{\bullet}+\mathrm{H}_{2} \mathrm{O} \rightarrow \mathrm{H}_{2}+\mathrm{OH}^{-} & k=7.8 \times 10^{9} \mathrm{dm}^{3} \mathrm{~mol}^{-1} \mathrm{~s}^{-1} \\
\mathrm{e}_{\mathrm{aq}}{ }^{-}+\mathrm{OH}^{\bullet} \rightarrow \mathrm{OH}^{-} & k=7.0 \times 10^{9} \mathrm{dm}^{3} \mathrm{~mol}^{-1} \mathrm{~s}^{-1} \\
\mathrm{H}^{\bullet}+\mathrm{H}^{\bullet} \rightarrow \mathrm{H}_{2} & k=5.5 \times 10^{9} \mathrm{dm}^{3} \mathrm{~mol}^{-1} \mathrm{~s}^{-1} \\
\mathrm{H}^{\bullet}+\mathrm{OH}^{\bullet} \rightarrow \mathrm{H}_{2} \mathrm{O} & k=1.44 \times 10^{11} \mathrm{dm}^{3} \mathrm{~mol}^{-1} \mathrm{~s}^{-1} \\
\mathrm{OH}^{\bullet}+\mathrm{OH}^{\bullet} \rightarrow \mathrm{H}_{2} \mathrm{O}_{2} & \\
\mathrm{H}_{\mathrm{aq}}{ }^{+}+\mathrm{OH}^{-} \rightarrow \mathrm{H}_{2} \mathrm{O} &
\end{array}
$$

Although reactions 8-10 are important in determining $\mathrm{G}\left(\mathrm{H}_{2}\right)$ from aqueous solution, ${ }^{28}$ the greatest contribution ( $>70 \%$ ) comes from the fragmentation of $\mathrm{H}_{2} \mathrm{O}$ * (reaction 4), produced by either direct excitation (reaction 2) or recombination (reaction 5). The decrease in $G\left(\mathrm{H}_{2}\right)$ in aqueous solutions of nitrate is a consequence of $\mathrm{NO}_{3}{ }^{-}$quenching and scavenging the precursors to $\mathrm{H}_{2}$ (i.e. $\mathrm{H}_{2} \mathrm{O}^{*}$, $\mathrm{e}_{\text {pre }}{ }^{-}$, $\mathrm{e}_{\mathrm{aq}}{ }^{-}$, and $\mathrm{H}^{*}$ ). ${ }^{2,36-38}$

$$
\begin{array}{ll}
\mathrm{NO}_{3}{ }^{-}+\mathrm{H}_{2} \mathrm{O}^{*} \rightarrow \mathrm{NO}_{3}{ }^{-*}+\mathrm{H}_{2} \mathrm{O} & k=1 \times 10^{13} \mathrm{dm}^{3} \mathrm{~mol}^{-1} \mathrm{~s}^{-1} \\
\mathrm{NO}_{3}{ }^{-}+\mathrm{e}_{\mathrm{pre}}{ }^{-} \rightarrow \mathrm{NO}_{3}{ }^{-2-} & k=1 \times 10^{13} \mathrm{dm}^{3} \mathrm{~mol}^{-1} \mathrm{~s}^{-1} \\
\mathrm{NO}_{3}{ }^{-}+\mathrm{e}_{\mathrm{aq}}{ }^{-} \rightarrow \mathrm{NO}_{3}{ }^{-2-} & k=9.7 \times 10^{9} \mathrm{dm}^{3} \mathrm{~mol}^{-1} \mathrm{~s}^{-1} \\
\mathrm{NO}_{3}{ }^{-}+\mathrm{H}^{\cdot} \rightarrow \mathrm{HNO}_{3}{ }^{-} & k=5.6 \times 10^{6} \mathrm{dm}^{3} \mathrm{~mol}^{-1} \mathrm{~s}^{-1}
\end{array}
$$

Stochastic radiation track calculations for the $\gamma$-irradiation of aerated aqueous nitrate solutions, including both quenching and scavenging processes, are included in Figure 1 and are in very 
good agreement with the corresponding experimental data for both nitrate and nitric acid solutions. $^{2}$

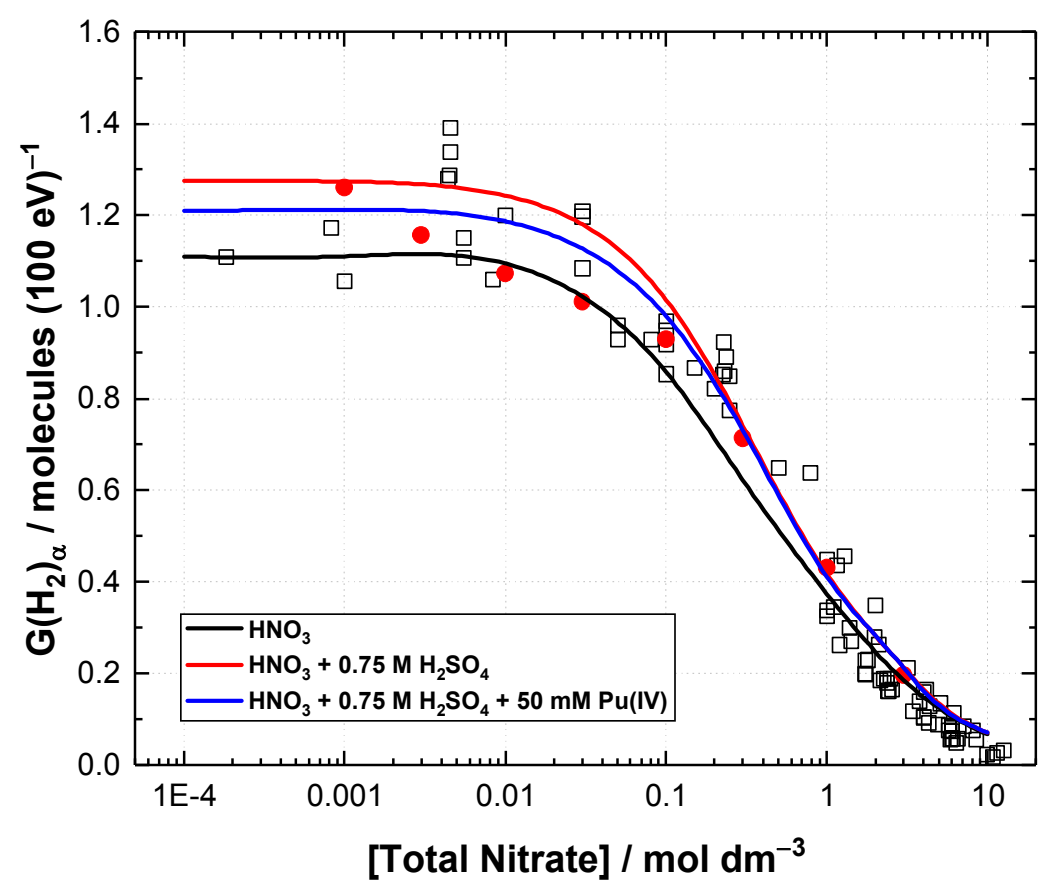

Figure 4. $\mathrm{G}\left(\mathrm{H}_{2}\right)_{\alpha}$ as a function of total nitrate concentration: $\alpha$-radiolysis of $\mathrm{HNO}_{3}$ solutions for self-radiolysis by $\mathrm{Am}, \mathrm{Cm}, \mathrm{Po}$, and $\mathrm{Pu}(\square)^{10 \text {,Error! Bookmark not defined.-Error! Bookmark not defined. }}$, as shown in Figure 2 and Figure 3; $5 \mathrm{MeV} \mathrm{He}^{2+}$ ion radiolysis of deaerated aqueous $\mathrm{NO}_{3}{ }^{-}(\mathbf{O})^{39}$ solutions. Solid curves are for stochastic calculations for $\mathrm{HNO}_{3}$ (Black Curve), $\mathrm{HNO}_{3}+0.75 \mathrm{M}$ $\mathrm{H}_{2} \mathrm{SO}_{4}$ (Red Curve), and $\mathrm{HNO}_{3}+0.75 \mathrm{M} \mathrm{H}_{2} \mathrm{SO}_{4}+50 \mathrm{mM} \mathrm{Pu}(\mathrm{IV})$ (Blue Curve).

Modelling has been extended to the case of $5 \mathrm{MeV} \alpha$-irradiation of aerated solutions of nitric acid, covering the experimental conditions used in this work and in deaerated nitrate solutions from previous ion accelerator studies. ${ }^{39}$ The results are plotted in Figure 4 alongside the previously discussed experimental data, as a function of total nitrate concentration. The $\mathrm{G}\left(\mathrm{H}_{2}\right)_{\alpha}$ values from the stochastic calculations are in good agreement with the corresponding experimental data. With regards to aerated solutions of $\mathrm{HNO}_{3}$, the yields of the $\alpha$-radiation track reactions responsible for $\mathrm{H}_{2}$ formation as a function of $\mathrm{HNO}_{3}$ concentration are given in Table 2, along with their calculated radiolytic yields. In pure water, the two most important $\mathrm{H}_{2}$ production pathways are dissociation of $\mathrm{H}_{2} \mathrm{O}^{*}$ (reaction 4) and the reaction of the $\mathrm{e}_{\mathrm{aq}}{ }^{-}$with $\mathrm{H}^{\bullet}$ (reaction 10). 
Table 2. Calculated $\alpha$-radiation track reaction yields for reactions producing molecular hydrogen from aerated water and aerated nitric acid $\left(1 \times 10^{-4}\right.$ to $\left.10 \mathrm{~mol} \mathrm{dm}^{-3}\right)$, taken at $1 \mu$ s for a $3 \mathrm{MeV}$ $\mathrm{He}^{2+}$ ion (Mean LET $=1.44 \times 10^{2} \mathrm{eV} \mathrm{nm}^{-1}$ ).

\begin{tabular}{|c|c|c|c|c|c|c|c|}
\hline \multirow[t]{2}{*}{ Reaction } & \multirow{2}{*}{$\begin{array}{l}\text { Aerated } \\
\text { Water }\end{array}$} & \multicolumn{6}{|c|}{$\begin{array}{c}{\left[\mathbf{H N O}_{3}\right]} \\
\left(\mathrm{mol} \mathrm{dm}^{-3}\right)\end{array}$} \\
\hline & & $10^{-4}$ & $10^{-3}$ & $10^{-2}$ & $10^{-1}$ & 1 & 10 \\
\hline $2 \mathrm{e}_{\mathrm{aq}}{ }^{-}+2 \mathrm{H}_{2} \mathrm{O} \rightarrow \mathrm{H}_{2}+2 \mathrm{OH}^{-}(\mathbf{9})$ & 0.11 & 0.10 & 0.09 & 0.08 & 0.04 & 0.00 & 0.00 \\
\hline $\mathrm{e}_{\mathrm{aq}}{ }^{-}+\mathrm{H}^{\bullet}+\mathrm{H}_{2} \mathrm{O} \rightarrow \mathrm{H}_{2}+\mathrm{OH}^{-}(\mathbf{1 0})$ & 0.31 & 0.31 & 0.29 & 0.19 & 0.06 & 0.00 & 0.00 \\
\hline $\mathrm{H}^{\bullet}+\mathrm{H}^{\bullet} \rightarrow \mathrm{H}_{2}(\mathbf{1 2})$ & 0.07 & 0.06 & 0.11 & 0.18 & 0.14 & 0.05 & 0.03 \\
\hline $\mathrm{H}_{2} \mathrm{O}^{*} \rightarrow \mathrm{O}\left({ }^{3} \mathrm{P} /{ }^{1} \mathrm{D}\right)+\mathrm{H}_{2}(4)$ & 0.62 & 0.64 & 0.62 & 0.66 & 0.56 & 0.34 & 0.08 \\
\hline
\end{tabular}

As the acidity of the solution increases with $\mathrm{HNO}_{3}$ concentration, the yield of reaction $\mathbf{1 2}$ increases going from 0.07 in pure water to 0.18 at $1 \times 10^{-2} \mathrm{~mol} \mathrm{dm}^{-3} \mathrm{HNO}_{3}$, which corresponds to a change in $\mathrm{pH}$ from $\sim 7$ to 2 . This is a consequence of the presence of $\mathrm{H}_{\mathrm{aq}}{ }^{+}$which has long been noted as an effective scavenger of both $\mathrm{e}_{\mathrm{pre}}{ }^{-}$and $\mathrm{e}_{\mathrm{aq}}{ }^{-}$(reactions 20 and 21, respectively) ${ }^{34}$

$$
\begin{array}{ll}
\mathrm{e}_{\mathrm{pre}}{ }^{-}+\mathrm{H}_{\mathrm{aq}}{ }^{+} \rightarrow \mathrm{H}^{\bullet} & k=2.18 \times 10^{12} \mathrm{dm}^{3} \mathrm{~mol}^{-1} \mathrm{~s}^{-1} \\
\mathrm{e}_{\mathrm{aq}}{ }^{-}+\mathrm{H}_{\mathrm{aq}}{ }^{+} \rightarrow \mathrm{H}^{\bullet} & k=2.3 \times 10^{10} \mathrm{dm}^{3} \mathrm{~mol}^{-1} \mathrm{~s}^{-1}
\end{array}
$$

For $\mathrm{HNO}_{3}$ concentrations below the threshold for scavenging $\mathrm{e}_{\mathrm{pre}}{ }^{-}, \mathrm{H}_{\mathrm{aq}}{ }^{+}$scavenges $\sim 70 \%$ of the $\mathrm{e}_{\mathrm{aq}}{ }^{-}$that in a nitrate solution of neutral $\mathrm{pH}$ would be scavenged by $\mathrm{NO}_{3}{ }^{-}$, as shown in Table 3 . This leads to the formation of higher concentrations of $\mathrm{H}^{*}$, which reacts almost three magnitudes slower with $\mathrm{NO}_{3}{ }^{-}$than $\mathrm{e}_{\mathrm{aq}}{ }^{-}$. Consequently, more $\mathrm{e}_{\mathrm{aq}}{ }^{-}$is converted to $\mathrm{H}_{2}$ via $\mathrm{H}^{\bullet}$, albeit dissolved $\mathrm{O}_{2}$ scavenges a notable fraction of the additional $\mathrm{H}^{*}$. This condition is maintained until the concentration of $\mathrm{NO}_{3}{ }^{-}$is sufficiently high to begin quenching $\mathrm{H}_{2} \mathrm{O}^{*}$ and scavenging $\mathrm{e}_{\mathrm{pre}}{ }^{-}$. With regards to the latter, $\mathrm{NO}_{3}{ }^{-}$is a more effective scavenger than $\mathrm{H}_{\mathrm{aq}}{ }^{+}$, consuming $\sim 82 \%$ of the $\mathrm{e}_{\mathrm{pre}}{ }^{-}$ that would be scavenged by $\mathrm{NO}_{3}{ }^{-}$, relative to complementary neutral $\mathrm{pH}$ nitrate solutions 
Table 3. Percentage partitioning of $\mathrm{e}_{\mathrm{aq}}{ }^{-}$and $\mathrm{e}_{\mathrm{pre}}{ }^{-}$between $\mathrm{NO}_{3}{ }^{-}$and $\mathrm{H}_{\mathrm{aq}}{ }^{+}$in aqueous $\mathrm{HNO}_{3}$ as a function of their respective scavenging capacities.

\begin{tabular}{l|l}
\hline Reaction & $\begin{array}{l}\text { Percentage Partitioning } \\
(\%)\end{array}$ \\
\hline $\mathrm{H}_{\mathrm{aq}}{ }^{+}+\mathrm{e}_{\mathrm{pre}}{ }^{-} \rightarrow \mathrm{H}^{\bullet}$ & 17.90 \\
\hline $\mathrm{NO}_{3}{ }^{-}+\mathrm{e}_{\mathrm{pre}}{ }^{-} \rightarrow \mathrm{NO}_{3}{ }^{-2-}$ & 82.10 \\
\hline $\mathrm{H}_{\mathrm{aq}}{ }^{+}+\mathrm{e}_{\mathrm{pre}}{ }^{-} \rightarrow \mathrm{H}^{\bullet}$ & 70.34 \\
\hline $\mathrm{NO}_{3}{ }^{-}+\mathrm{e}_{\mathrm{aq}}{ }^{-} \rightarrow \mathrm{NO}_{3}{ }^{-2-}$ & 29.66 \\
\hline
\end{tabular}

Table 4 gives the calculated radiolytic yields of the $\alpha$-radiation track reactions responsible for inhibiting $\mathrm{H}_{2}$ formation as a function of $\mathrm{HNO}_{3}$ concentration. At low $\mathrm{HNO}_{3}$ concentrations, $\mathrm{G}\left(\mathrm{H}_{2}\right)_{\alpha}$ is controlled by the reactions of $\mathrm{e}_{\mathrm{aq}}{ }^{-}$and $\mathrm{H}^{*}$ with $\mathrm{OH}^{*}$ and $\mathrm{O}_{2}$, and to a lesser extent by $\mathrm{H}_{2} \mathrm{O}_{2}$ with $\mathrm{e}_{\mathrm{aq}}{ }^{-}$; therefore, in the absence of oxygen the accelerator studies give a higher yield at the low nitrate concentration limit than the radionuclide experiments in aerated nitric acid. As the concentration of $\mathrm{HNO}_{3}$ increases, scavenging of $\mathrm{e}_{\mathrm{aq}}{ }^{-}$by nitrate becomes increasingly important, balancing the increased significance of reaction $\mathbf{1 2}$ and $\mathbf{2 1}$ so that there is no change in the yield of $\mathrm{H}_{2}$ up to $1 \times 10^{-2} \mathrm{~mol} \mathrm{dm}^{-3} \mathrm{HNO}_{3}$. At higher nitrate concentrations quenching and scavenging of $\mathrm{H}_{2} \mathrm{O}^{*}$, $\mathrm{e}_{\text {pre }}{ }^{-}$and $\mathrm{H}^{*}$ become the main reactions of inhibiting $\mathrm{H}_{2}$ formation. 
Table 4. Calculated $\alpha$-radiation track reaction yields, for the most important reactions inhibiting molecular hydrogen production from aerated water and aerated nitric acid $\left(1 \times 10^{-4}\right.$ to $\left.10 \mathrm{~mol} \mathrm{dm}^{-3}\right)$, taken at $1 \mu \mathrm{s}$ for a $3 \mathrm{MeV} \mathrm{He}^{2+}$ ion $\left(\right.$ Mean LET $=1.44 \times 10^{2} \mathrm{eV} \mathrm{nm}^{-1}$ ).

\begin{tabular}{|c|c|c|c|c|c|c|c|}
\hline \multirow{2}{*}{ Reaction } & \multirow{2}{*}{$\begin{array}{l}\text { Aerated } \\
\text { Water }\end{array}$} & \multicolumn{6}{|c|}{$\begin{array}{c}{\left[\mathbf{H N O}_{3}\right]} \\
\left(\mathrm{mol} \mathrm{dm}^{-3}\right)\end{array}$} \\
\hline & & $10^{-4}$ & $10^{-3}$ & $10^{-2}$ & $10^{-1}$ & 1 & 10 \\
\hline $\mathrm{e}_{\mathrm{aq}}{ }^{-}+\mathrm{H}_{2} \mathrm{O}_{2} \rightarrow \mathrm{OH}^{-}+\mathrm{OH}^{\bullet}$ & 0.44 & 0.40 & 0.30 & 0.13 & 0.01 & 0.00 & 0.00 \\
\hline $\mathrm{e}_{\mathrm{aq}}^{-}+\mathrm{O}\left({ }^{3} \mathrm{P}\right) \rightarrow \mathrm{O}^{\bullet-}$ & 0.07 & 0.05 & 0.04 & 0.03 & 0.01 & 0.00 & 0.00 \\
\hline $\mathrm{e}_{\mathrm{aq}}^{-}+\mathrm{HO}_{2}{ }^{-} \rightarrow \mathrm{HO}_{2}^{-}$ & 0.02 & 0.02 & 0.01 & 0.00 & 0.00 & 0.00 & 0.00 \\
\hline $\left.\mathrm{H}^{\bullet}+\mathrm{O}^{3} \mathrm{P}\right) \rightarrow \mathrm{OH}^{\bullet}$ & 0.03 & 0.03 & 0.02 & 0.05 & 0.03 & 0.02 & 0.00 \\
\hline $\mathrm{H}^{\bullet}+\mathrm{HO}_{2}^{\bullet} \rightarrow \mathrm{H}_{2} \mathrm{O}_{2}$ & 0.04 & 0.05 & 0.09 & 0.08 & 0.06 & 0.02 & 0.01 \\
\hline $\mathrm{OH}^{\bullet}+\mathrm{e}_{\mathrm{aq}}^{-} \rightarrow \mathrm{OH}^{-}$ & 0.98 & 1.02 & 0.90 & 0.49 & 0.08 & 0.00 & 0.00 \\
\hline $\mathrm{OH}^{\bullet}+\mathrm{H}^{\bullet} \rightarrow \mathrm{H}_{2} \mathrm{O}$ & 1.08 & 1.06 & 1.11 & 1.24 & 1.34 & 0.73 & 0.29 \\
\hline $\mathrm{O}_{2}+\mathrm{e}_{\mathrm{aq}}^{-} \rightarrow \mathrm{O}_{2}^{\cdot-}$ & 0.37 & 0.29 & 0.11 & 0.04 & 0.00 & 0.00 & 0.00 \\
\hline $\mathrm{O}_{2}+\mathrm{H}^{\bullet} \rightarrow \mathrm{HO}_{2}^{\bullet}$ & 0.42 & 0.52 & 0.68 & 0.80 & 0.69 & 0.38 & 0.15 \\
\hline $\mathrm{NO}_{3}^{-}+\mathrm{e}_{\mathrm{pre}}^{-} \rightarrow \mathrm{NO}_{3}^{\cdot 2-}$ & 0.00 & 0.00 & 0.01 & 0.10 & 0.89 & 2.51 & 2.75 \\
\hline $\mathrm{NO}_{3}{ }^{-}+\mathrm{e}_{\mathrm{aq}}^{-} \rightarrow \mathrm{NO}_{3}{ }^{\cdot 2-}$ & 0.00 & 0.06 & 0.20 & 0.57 & 0.68 & 0.17 & 0.00 \\
\hline $\mathrm{NO}_{3}^{-}+\mathrm{H}^{\bullet} \rightarrow \mathrm{HNO}_{3}^{-}$ & 0.00 & 0.00 & 0.00 & 0.00 & 0.02 & 0.07 & 0.26 \\
\hline $\begin{array}{l}\mathrm{NO}_{3}{ }^{-}+\mathrm{H}_{2} \mathrm{O}^{*} \rightarrow \mathrm{NO}_{3} *+ \\
\mathrm{H}_{2} \mathrm{O}\end{array}$ & 0.00 & 0.00 & 0.00 & 0.03 & 0.30 & 1.55 & 2.79 \\
\hline
\end{tabular}

Actinide solutions were prepared in sulfuric acid solution for low $\mathrm{HNO}_{3}$ concentrations $\left(<0.1 \mathrm{~mol} \mathrm{dm}^{-3}\right)$. Under these conditions $\mathrm{G}\left(\mathrm{H}_{2}\right)_{\alpha}$ is higher than calculated for pure $\mathrm{HNO}_{3}$ solutions but has similar insensitivity up to $1 \times 10^{-2} \mathrm{~mol} \mathrm{dm}^{-3} \mathrm{HNO}_{3}$. In this case, scavenging of $\mathrm{e}_{\mathrm{aq}}{ }^{-}$by $\mathrm{H}_{\mathrm{aq}}{ }^{+}$is dominant until nitrate reaches $1 \times 10^{-2} \mathrm{~mol} \mathrm{dm}^{-3}$ and effectively competes for scavenging of precursors to $\mathrm{H}_{2}$ and reduces $\mathrm{G}\left(\mathrm{H}_{2}\right)_{\alpha}$. The higher yield of $\mathrm{H}_{2}$ from acidic solutions is consistent with analysis by Schwarz et al. who measured a higher yield from sulfuric acid vs. water at high LET. ${ }^{41}$ Valdimirova also measured $\mathrm{G}\left(\mathrm{H}_{2}\right)_{\alpha}$ increasing from 1.37 to 1.55 for the dose to water between 0.4 and $4 \mathrm{~mol} \mathrm{dm}^{-3} \mathrm{H}_{2} \mathrm{SO}_{4}$ using ${ }^{210} \mathrm{Po} \alpha$-irradiation. ${ }^{42}$ The observed increasing yield with acidity for $\alpha$-radiolysis differs from low LET $\gamma$-irradiation where, the $\mathrm{G}\left(\mathrm{H}_{2}\right)_{\gamma}$ is well established to decrease only slightly from about 0.44 in pure water to 0.41 in 
$0.4 \mathrm{~mol} \mathrm{dm}^{-3} \mathrm{H}_{2} \mathrm{SO}_{4}$ at room temperature. ${ }^{3,43}$ This is a consequence of LET effects promoting greater recombination of $\mathrm{H}^{\bullet}$ to $\mathrm{H}_{2}$, relative to gamma tracks.

Effect of Plutonium and Americium Concentration. Plutonium and americium are redox active and may react with species generated from the radiolysis for water. Of potential importance are the reactions of $\mathrm{Pu}(\mathrm{IV}) / \mathrm{Am}$ (III) with the precursors to $\mathrm{H}_{2}$, for example reactions 22 and 23. For these reactions to have a significant effect on $\mathrm{G}\left(\mathrm{H}_{2}\right)_{\alpha}$ they would need to be competitive with scavenging by nitrate ions (reactions 16-19). Rates coefficients for the reaction of $\mathrm{Pu}(\mathrm{IV})$ and $\mathrm{Am}(\mathrm{III})$ with the $\mathrm{e}_{\mathrm{aq}}{ }^{-}$and $\mathrm{H}^{\bullet}$ have been reported. ${ }^{44,45}$

$$
\begin{aligned}
& \mathrm{Pu}(\mathrm{IV}) / \mathrm{Am}(\mathrm{III})+\mathrm{e}_{\mathrm{aq}}{ }^{-} \rightarrow \mathrm{Pu}(\mathrm{III}) / \mathrm{Am}(\mathrm{II}) \\
& k_{P u(I V)}=4.2 \times 10^{10} \mathrm{dm}^{3} \mathrm{~mol}^{-1} \mathrm{~s}^{-1} \\
& k_{A m(I I I)}=2.3 \times 10^{8} \mathrm{dm}^{3} \mathrm{~mol}^{-1} \mathrm{~s}^{-1} \\
& \mathrm{Pu}(\mathrm{IV}) / \mathrm{Am}(\mathrm{III})+\mathrm{H}^{\bullet} \rightarrow \mathrm{Pu}(\mathrm{III}) / \mathrm{Am}(\mathrm{II})+\mathrm{H}^{+} \\
& k_{P u(I V)}=4.5 \times 10^{7} \mathrm{dm}^{3} \mathrm{~mol}^{-1} \mathrm{~s}^{-1}
\end{aligned}
$$

During preparation of solutions with lower acid concentrations disproportionation of $\mathrm{Pu}(\mathrm{IV})$ to $\mathrm{Pu}(\mathrm{III})$ and $\mathrm{Pu}(\mathrm{VI})$ will have occurred, reducing the potential role of reactions 22 and 23.

Preliminary calculations including these reactions of plutonium, shown in Figure 4 for $50 \mathrm{mM}$ $\mathrm{Pu}(\mathrm{IV})$ in solution, suggest that the reduction of $\mathrm{Pu}(\mathrm{IV})$ to $\mathrm{Pu}(\mathrm{III})$ may influence radiation track chemistry at $\mathrm{HNO}_{3}$ concentrations below $0.1 \mathrm{~mol} \mathrm{dm}^{-3}$. The decrease in $\mathrm{G}\left(\mathrm{H}_{2}\right)_{\alpha}$, relative to the corresponding $\mathrm{HNO}_{3}+0.75 \mathrm{~mol} \mathrm{dm}{ }^{-3} \mathrm{H}_{2} \mathrm{SO}_{4}$ system, at $1 \times 10^{-4} \mathrm{~mol} \mathrm{dm}^{-3}$ nitrate is directly related to $\mathrm{Pu}(\mathrm{IV})$ scavenging $\mathrm{e}_{\mathrm{aq}}{ }^{-}$, reaction 22 . The agreement is not exact, but a more complete model of the plutonium redox chemistry, and inclusion of reactions with other water radiolysis species, would be needed to refine the understanding of this system. The much lower concentration of americium than plutonium used in experiments, together with its lower reaction rate with $\mathrm{e}_{\mathrm{aq}}{ }^{-}$, implies it will not have a significant effect on $\mathrm{H}_{2}$ production.

Measurements in the range of 1 and $10 \mathrm{~mol} \mathrm{dm}^{-3}$ total nitrate showed no significant effect of plutonium concentration between 24 and $160 \mathrm{mM}$ on $\mathrm{G}\left(\mathrm{H}_{2}\right)_{\alpha}$ and data obtained from americium solutions were also consistent with plutonium solution measurements rather than 
tending towards the yields for ${ }^{244} \mathrm{Cm}$ and ${ }^{210} \mathrm{Po}$ solutions. These results imply no significant effect of plutonium redox chemistry on the molecular hydrogen yield. This is consistent with the

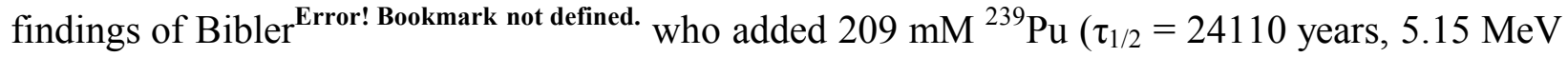
$\alpha$-particle) to ${ }^{244} \mathrm{Cm}$ solutions and did not observe a significant effect on the yield, although $\mathrm{G}\left(\mathrm{H}_{2}\right)_{\alpha}$ appears systematically higher than for plutonium solutions. In contrast, Kuno et al. ${ }^{\text {Error! }}$ Bookmark not defined. reported a significant decrease in $\mathrm{G}\left(\mathrm{H}_{2}\right)_{\alpha}$ as plutonium concentration was increased from 41 to $670 \mathrm{mM}$ for solution with 1 and $10 \mathrm{~mol} \mathrm{dm}^{-3}$ total nitrate. By extrapolating their data to zero plutonium concentration they found agreement with experiments of Bibler ${ }^{\text {Error! }}$ Bookmark not defined. using ${ }^{244} \mathrm{Cm}$ as the radiation source and proposed that scavenging of $\mathrm{e}_{\mathrm{aq}}{ }^{-}$or its precursors by plutonium explained the lower yield measured in plutonium solutions. For scavenging of precursors to $\mathrm{H}_{2}$ by plutonium to be significant between 1 and $10 \mathrm{~mol} \mathrm{dm}{ }^{-3} \mathrm{HNO}_{3}$ the rate of reaction with $\mathrm{e}_{\mathrm{pre}}{ }^{-}$or quenching of $\mathrm{H}_{2} \mathrm{O}^{*}$ would need to be competitive with the reactions of nitrate. No information on these rates is available, but since the concentration of plutonium is much less than nitrate in these experiments the rate coefficients would need to be of much greater magnitude than those for nitrate to significantly contribute. Consequently, the difference in $\mathrm{G}\left(\mathrm{H}_{2}\right)_{\alpha}$ for experiments using plutonium and ${ }^{244} \mathrm{Cm}$ and remains unexplained.

Comparison of Radionuclide and Accelerator Experiments. As outlined earlier, concerns have been raised regarding the use of accelerator experiments for replicating radionuclide $\alpha$ decay irradiations, owing to the very high local dose rates inherent in accelerator studies. ${ }^{31}$ The radionuclide experiments and stochastic calculations presented show little difference in $\mathrm{G}\left(\mathrm{H}_{2}\right)_{\alpha}$ relative to the corresponding accelerator experiments. As there is little difference between the $\mathrm{G}\left(\mathrm{H}_{2}\right)_{\alpha}$ values from accelerator and radionuclide experiments, it may be concluded that these two approaches to investigating the effects of $\alpha$-irradiation on matter are equivalent; at the very least in terms of $\mathrm{H}_{2}$ production from aqueous solutions. Furthermore, the results from the stochastic calculations are important for resolving this matter, as they reflect the limiting low dose, isolated track regime and, therefore, any significant effects attributed to dose rate would have become apparent in the calculated yields, which is not the case. Consequently, concerns attributed to the overlapping of tracks and/or non-homogeneous energy distribution through the use of very high local dose rates by accelerator studies may be considered to be unfounded with respect to the radiolytic formation of $\mathrm{H}_{2}$. This is not to say that dose rate effects do not play a part in the evolution of other water radiolysis species. 
On the other hand, the data presented show the challenges of using radionuclide studies to provide insight into radiation effects when using redox active metals, such as plutonium. At sufficiently high concentrations, redox active metals are able to influence the chemistry of an irradiated solution and in doing so alter the yields of observable radiolytic products. ${ }^{46,47,48}$ Preliminary calculations performed as part of this work, given in Figure 4, provide evidence for plutonium's influence on radiation track chemistry at low nitric acid concentrations $\left(\leq 1 \times 10^{-3} \mathrm{~mol} \mathrm{dm}^{-3}\right)$.

\section{CONCLUSIONS}

Measurements of $\mathrm{G}\left(\mathrm{H}_{2}\right)_{\alpha}$ from self-radiolysis by plutonium and americium containing solutions of aqueous nitric and its mixtures with sulfuric acid have been compared with radiation track modeling calculations. These show measurable differences in the variation of molecular hydrogen yield with nitrate concentration for pure nitric acid and nitric acid-sulfuric acid solutions, not seen for gamma irradiation. The differences can be explained using the prediction of stochastic radiation track models as resulting from scavenging of the $\mathrm{e}_{\mathrm{aq}}{ }^{-}$by $\mathrm{H}_{\mathrm{aq}}{ }^{+}$to form $\mathrm{H}^{\bullet}$. While plutonium has been shown to be an effective scavenger of precursors of molecular hydrogen below $0.1 \mathrm{~mol} \mathrm{dm}{ }^{-3}$ nitrate, previously reported effects of plutonium on $\mathrm{G}\left(\mathrm{H}_{2}\right)_{\alpha}$ between 1 and $10 \mathrm{~mol} \mathrm{dm}^{-3}$ nitric acid were not reproduced. Comparison between the radionuclide and accelerator experiments and model predictions leads to the conclusion that the high dose rate of accelerator studies does not significantly affect the measured $\mathrm{G}\left(\mathrm{H}_{2}\right)_{\alpha}$.

Validation of the stochastic radiation track modelling for $\alpha$-irradiation of nitric acid solutions against experimental $\mathrm{G}\left(\mathrm{H}_{2}\right)_{\alpha}$ values is the precursor to its use in more sophisticated multi-scale modelling involving bulk homogeneous reactions and plutonium redox chemistry, which recent studies have shown to be important in determining radiation chemical behaviour. ${ }^{46}$ From a practical perspective the data presented are relevant to safety assessments of laboratory wastes, reprocessing, and minor actinide partitioning flowsheets at higher plutonium concentrations, ${ }^{49,50}$ such as proposed for the "EURO-GANEX" flowsheet ${ }^{51}$ and also mixed oxide fuels reprocessing. ${ }^{52}$

\section{SUPPORTING INFORMATION}


Details of experimental samples (pdf)

\section{AUTHOR INFORMATION}

\section{Corresponding Authors}

Corresponding Author: Gregory P. Horne, gregory.horne@inl.gov

Robin M. Orr, robin.m.orr@nnl.co.uk

\section{ORCID}

Gregory P. Horne: 0000-0003-0596-0660.

Robin M. Orr: 0000-0002-5844-4849.

\section{ACKNOWLEDGMENT}

We acknowledge financial support from the European Commission (SACSESS project FP7-FISSION-2012-323282), Sellafield Ltd., the UK Department for Energy and Climate Change, the UK Engineering and Physical Sciences Research Council (EPSRC) (EP/F013809/1, EP/I002855/1 and EP/I034106), the National Nuclear Laboratory (NNL), the UK Nuclear Decommissioning Authority (NDA), and the Dalton Cumbrian Facility, a joint initiative of the NDA and the University of Manchester. G. P. Horne was supported by a Ph.D. studentship from the EPSRC Nuclear FiRST Doctoral Training Centre at The University of Manchester (EP/G037140/1).

Plutonium isotopic analyses were made by Sellafield Analytical Services and NNLSellafield Analytical Team. J. Brown, C. Campbell and J. Holt are thanked for assistance with the plutonium experiments.

\section{REFERENCES}

(1) Davis, W.; De Bruin, H. J. New Activity Coefficients of 0 - 100 Per Cent Aqueous Nitric Acid. J. Inorg. Nucl. Chem., 1964, 26, 1069-1083.

(2) Horne, G. P.; Pimblott, S. M.; LaVerne, J. A. Inhibition of Radiolytic Molecular Hydrogen Formation by Quenching of Excited State Water. J. Phys. Chem. B, 2017, 121, 5385-5390.

(3) Schwartz, H.A. The Effect of Molecular Yields in the Radiolysis of Aqueous Solutions. Am. Chem. Soc. 1955, 77, 4960-4964. 
(4) Yoshida, K.; Abe, H.; Yamane, Y.; Tashiro, S.; Muramatsu, K. Research on the State-ofthe-Art of Accident Consequence Analysis Method for Non-Reactor Nuclear Facilities (1). JAEA. $\quad$ http://jolissrch-inter.tokai-sc.jaea.go.jp/pdfdata/JAEA-Research-2007-047.pdf. 2007.

(5) May, R.; White, H. P. The Radiolysis of Nitric Acid in Highly Active Concentrates; Technical Report AERE-R-8646 for the Atomic Energy Research Establishment: Harwell, England, January 1977.

(6) Draganic, Z.D.; Draganic, I. G. Formation of Primary Yields of Hydrogen Peroxide and Molecular Hydrogen $\left(\mathrm{GH}_{2} \mathrm{O}_{2}\right.$ and $\left.\mathrm{GH}_{2}\right)$ in the Gamma. Radiolysis of Neutral Aqueous Solutions. J. Phys. Chem. 1971, 75, 3950-3957.

(7) Mahlman, H.A. The "Direct Effect" in the Radiolysis of Aqueous Sodium Nitrate Solutions. J. Phys. Chem. 1963, 67, 1466-1469.

(8) Pastina, B.; LaVerne, J. A.; Pimblott, S. M. Dependence of Molecular Hydrogen Formation in Water on Scavengers of the Precursor to the Hydrated Electron. J. Phys. Chem. A 1999, 103, 5841-5846.

(9) Mahlman, H. A. The OH Yield in the Co60 $\gamma$ Radiolysis of $\mathrm{HNO}_{3}$. J. Chem. Phys. 1961, 35, 936-939.

(10) Kazanjian, A. R.; Miner, F. J.; Brown, A. K.; Hagan, P. G.; Berry, J. W. Radiolysis of Nitric Acid Solution: L.E.T. Effects. Trans. Faraday Soc. 1970, 66, 2192-2198.

(11) Mahlman, H. A. Activity Concept in Radiation Chemistry. J. Chem. Phys. 1959, 31, 993995.

(12) Nakagiri, N.; Miyata, T. Evaluation of Value for Hydrogen Release from High Level Liquid Waste .1. Gamma Ray Radiolysis of Aqueous Nitric Acid Solutions. J. Atomic Energy Soc. Japan 1994, 36, 744-751.

(13) Burns, W. G.; May, R.; White, H. P. Storage of PFR Highly Active Waste. $7 b$ - Radiolytic Study. Final Report; Technical Report AEAE-R-8595 for the Atomic Energy Research Establishment: Harwell, England, January 1977.

(14) Rodenas, L. G.; Prini, R. F.; Liberman, S. J. Radiolysis of Aqueous Solutions of Gadolinium Nitrate. J. Radioanal. Nucl. Chem. Art. 1990, 139, 277-286.

(15) Elliot, A. J.; Bartels, D. M. The Reaction Set, Rate Constants and G-Values for the Simulation of the Radiolysis of Light Water Over the Range $20^{\circ}$ to $350^{\circ} \mathrm{C}$ Based on Information Available in 2008. AECL Nuclear Platform Research and Development Report 153-127160-450-001. 2009.

(16) Kazanjian, A. R.; Horrell, D. R. Radiolytically Generated Gases in Plutonium-Nitric Acid Solutions. Radiation Effects 1972, 13, 277-280.

(17) Sheppard, J.C. Alpha Radiolysis of Plutonium(IV)-Nitric Acid Solutions; Technical Report BNWL-751 for Pacific Northwest Laboratory: Richland, WA, May 1968.

(18) Kuno, Y.; Hina, T.; Masui, J. Radiolytically Generated Hydrogen and Oxygen from Plutonium Nitrate Solutions. J. Nucl. Sci. Tech. 1993, 30, 919-925. 
(19) Savel'ev, Y. I.; Ershova, Z. V.; Vladimirova, M. V. Alpha-Radiolysis of Aqueous Solutions of Nitric Acid. Radiokhimiya 1967, 9, 225-230.

(20) Bibler, N. E. Curium-244 $\alpha$ Radiolysis of Nitric Acid. Oxygen Production from Direct Radiolysis of Nitrate Ions. J. Phys. Chem. 1974, 78, 211-215.

(21) Spinks, J. W. T.; Woods, R. J. An Introduction to Radiation Chemistry; Third Edition; Wiley-Interscience: New York, 1990.

(22) Vladimirova, M. V. Alpha Radiolysis of Aqueous Solutions, Russ. Chem. Rev. (Engl. Transl.) 1964, 33, 212-219.

(23) Trumbore, C. N.; Hart, E. $\alpha$-Ray Oxidation of Ferrous Sulfate in 0.4 M Sulfuric Acid Solutions. The Effect of 0 to 0.4 M Oxygen, J. Chem. Phys. 1959, 63, 807-873.

(24) Lefort, M.; Tarrago, X. Radiolysis of Water by Particles of High Linear Energy Transfer. The Primary Yields in Aqueous Acid Solutions of Ferrous Sulfate and in Mixtures of Thallous and Ceric Ions. J. Chem. Phys. 1959, 63, 833-836.

(25) Lefort, M. Decomposition de L'eau par le Raynnement Alpha. J. Chim. Phys. 1951, 48, 339-343.

(26) Lefort, M. Radiochimie des Solutions Aqueuses. J. Chim. Phys. 1954, 51, 351-353.

(27) Senvar, C.; Hart, E. Proceedings of the Second United Nations International Conference on Peaceful Uses of Atomic Energy. 1958, 29, 19

(28) Burns, W. G.; Sims, H. E. Effect of Radiation Type in Water Radiolysis. J. Chem. Soc., Faraday Trans. 1: Physical Chemistry in Condensed Phases 1981, 77, 2803-2813.

(29) Crumière, F.; Vandenbore, J.; Essehli, R.; Blain, G.; Barbet, J.; Fattahi, M. LET Effects on the Hydrogen Production Induced by the Radiolysis of Pure Water. Rad. Phys. Chem. 2013, 82, 74-79.

(30) J.F. Ziegler, SRIM - The Stopping and Range of Ions in Matter, 2013, see <http:// www.srim.org/>.

(31) Trummer, M; Jonsson, M. Resolving the $\mathrm{H}_{2}$ effect on radiation induced dissolution of $\mathrm{UO}_{2}$-based spent nuclear fuel, J. Nucl. Mater. 2010, 396, 163-169.

(32) Walther, C.; Cho, H. R.; Marquardt, C. M.; Neck, V.; Seibert, A.; Yun, J. I.; Fanghaenel, T. Hydrolysis of Plutonium(IV) in Acidic Solutions: No Effect of Hydrolysis on Absorption-Spectra of Mononuclear Hydroxide Complexes. Radiochimica Acta 2007, 95, 7-16.

(33) Pimblott, S. M.; LaVerne, J. A. Effects of Track Structure on the Ion Radiolysis of the Fricke Dosimeter. J. Phys. Chem. A 2002, 106, 9420-9427.

(34) Buxton, G. V. Radiation Chemistry-Principles and Applications, VCH, New York and Germany, 1987.

(35) Gauduel, Y.; Pommeret, S.; Migus, A.; Antonetti, A. Femtosecond Dynamics of Geminate Pair Recombination in Pure Liquid Water. J. Phys. Chem., 1989, 93, 3880-3882. 
(36) Pimblott, S. M.; LaVerne, J. A. On the Radiation Chemical Kinetics of the Precursor to the Hydrated Electron. J. Phys. Chem. A 1998, 102, 2967-2975.

(37) Buxton, G. V.; Greenstock, C. L.; Helman, W. P. Ross, A. B. Critical Review of Rate Constants for Reactions of Hydrated Electrons, Hydrogen Atoms and Hydroxyl Radicals $\left({ }^{\circ} \mathrm{OH} /{ }^{\circ} \mathrm{O}^{-}\right)$in Aqueous Solution. J. Phys. Chem. Ref. Data 1988, 17, 513-886.

(38) Mezyk, S. P.; Bartels, D. M. Direct EPR Measurement of Arrehenius Parameters for the Reactions of $\mathrm{H} \cdot$ Atoms with $\mathrm{H}_{2} \mathrm{O}_{2}$ and $\mathrm{D} \cdot$ Atoms in Aqueous Solution. J. Chem. Soc. Faraday Trans., 1995, 91, 3127-3132.

(39) Huerta, M. P. Hydrogen Atom Formation in the Gamma and Heavy Ion Radiolysis of Aqueous Systems, Ph.D. Thesis, The University of Manchester, 2010.

(41) Schwarz, H. A.; Caffrey, J. M.; Scholes, G. Radiolysis of Neutral Water by Cyclotron Produced Deuterium and Helium Ions, J. Am. Chem. Soc. 1959, 81, 1801-1809.

(42) Vladimirova, M.; Ershova, Z. Trudy 2 Vsesoyuznogo Soveschchaniya po Radiatsionnoi Khimii, (Proceedings of the Second All-Union Conference on Radiation Chemistry). Akad. Nauk SSSR, $1962,162$.

(43) Hayon, E. Effect of Solute Concentration on the Recombination of $\mathrm{H}$ and $\mathrm{OH}$ in $\gamma$ Irradiated Aqueous solutions, J. Phys. Chem. 1961, 65, 1502-1505.

(44) Gogolev, A.V.; Shilov, V. P.; Fedoseev, A. M.; Pikaev, A. K. The Study of Reactivity of Actinide Ions Towards Hydrated Electrons and Hydrogen Atoms in Acid Aqueous Solutions by a Pulse Radiolysis Method. Int. J. Rad. Applic. Instr. Part C. Rad. Phys. Chem. 1991, 37, 531-535.

(45) Pikaev, A.K.; Gogolev, A.V.; Shilov, V.P.; Fedoseev, A.M. Reactivity of Ions of Actinides Towards Inorganic Free Radicals in Irradiated Aqueous Solutions. Isotopenpraxis. 1990, $26,465-469$.

(46) Horne, G.P.; Gregson, C.R.; Sims, H.E.; Orr, R.M.; Taylor, R.J.; Pimblott, S.M. Plutonium and Americium Alpha Radiolysis of Nitric Acid Solutions. J. Phys. Chem. B 2017, 121, 883-889.

(47) Horne, G.P.; Grimes, T.S.; Mincher, B.J.; Mezyk, S.P. Re-evaluation of Neptunium-nitric Acid Radiation Chemistry by Multi-Scale Modeling. J. Phys. Chem. B 2016, 120, 1264312649.

(48) Grimes, T. S.; Horne, G. P.; Dares, C. J.; Pimblott, S. M.; Mezyk, S. P.; Mincher, B. J. Kinetics of the Autoreduction of Hexavalent Americium in Aqueous Nitric Acid. Inorg. Chem. 2017, 56, 8295-8301.

(49) Bourg, S.; Hill, C.; Caravaca, C.; Rhodes, C.; Ekberg, C.; Taylor, R.; Geist, A.; Modolo, G.; Cassayre, L.; Malmbeck, R.; Harrison, M.; Angelis, G.; Espartero, A.; Bouvet, S.; Ouvrier, N. ACSEPT-Partitioning Technologies and Actinide Science: Towards Pilot Facilities in Europe. Nuclear Engineering and Design 2011, 241, 3427-3435.

(50) Bourg, S.; Geist A.; Narbutt J. SACSESS - the EURATOM FP7 Project on Actinide Separation from Spent Nuclear Fuels. Nukleonika 2015, 60, 809-814. 
(51) Carrott, M.; Bell, K.; Brown, J.; Geist, A.; Gregson, C.; Heres, X.; Maher, C.; Malmbeck, R.; Mason, C.; Modolo, G.; Mullich, U.; Sarsfield, M.; Wilden, A.; Taylor, R. Spiked Demonstration of a New Flowsheet for Co-Separating the Transuranic Actinides: the "EURO-GANEX" Process. Solv. Extr. Ion Exch. 2014, 32, 447-467.

(52) Birkett, J. E.; Carrott, M. J.; Fox, O. D.; Jones, C. J.; Maher, C. J.; Roube, C. V.; Taylor, R. J.; Woodhead, D. A. Controlling Neptunium and Plutonium within Single Cycle Solvent Extraction Flowsheets for Advanced Fuel Cycles. J. Nucl. Sci. Tech. 2007, 44, 337-343. 
Table of Contents Graphic

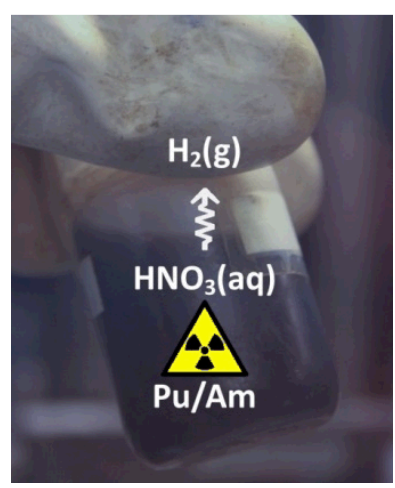

